\title{
Watching Paint Dry: Organic Solvent Syndrome in late-Twentieth-Century Britain
}

\begin{abstract}
ANNE SPURGEON*
In 1856 a Parisian physician called Auguste Delpech presented a paper to the French Academy of Medicine in which he described the strange behaviour of workers employed in the production of India rubber. Many of these men, Delpech reported, had symptoms of mental derangement resembling acute alcohol intoxication. They suffered from impaired memory, vague and confused thoughts, restlessness and insomnia. In particular, they exhibited changeable moods of hilarity and manic outbursts followed by drowsiness, apathy and inertia. ${ }^{1}$ The source of the problem, accurately identified by Delpech, was the inhalation of large quantities of a highly neurotoxic compound called carbon disulphide. This was used to soften and spread the latex gum in order to produce rubber sheets. Early rubber making was largely a cottage industry, carried out in poorly ventilated workrooms. With the expansion of the industry into larger scale production during the second half of the nineteenth century, further reports of "insanity" associated with rubber manufacture began to appear in the medical literature. In 1902, the physician Thomas Oliver, reporting on the British Committee on Dangerous Trades of 1899, described episodes during the manufacture of mackintoshes in which workers suffered from "an extremely violent maniacal condition whereby, in their frenzy, [they] have precipitated themselves from the top rooms of the factory to the ground". ${ }^{2}$ It was further observed that the windows of rubber vulcanizing rooms were frequently barred as a preventive measure.

The use of carbon disulphide represents one of the first industrial applications of a group of substances which, although chemically diverse, tend to be referred to collectively as "organic solvents". Experimental chemical production of these substances began in the late eighteenth century and their subsequent development for use in a range of manufacturing processes expanded rapidly throughout the nineteenth century. By the middle of the twentieth century they were ubiquitous in industry, employed, for example, in the production of paints and varnishes, glues, printing inks, degreasing agents, household cleaners, plastics, as well as pharmaceuticals and cosmetics. ${ }^{3}$ One consequence of this was that by the mid-1900s several million workers worldwide were exposed to organic solvents on a

(C) Anne Spurgeon 2006

*Dr Anne Spurgeon, Centre for the History of Medicine, University of Birmingham, Edgbaston, Birmingham B15 2TT, UK.

The author gratefully acknowledges the support of the Wellcome Trust for this work through a Research Leave Award. Special thanks are also due to my colleagues at the Centre for the History of Medicine, University of Birmingham, for all their help, advice and support during my time in the department.

\footnotetext{
${ }^{1}$ A Delpech, 'Notes sur les accidents que développe, chez les ouvriers en caoutchouc, l'inhalation du sulfure de carbone en vapeur', Gaz. Hebd. méd. Chir., 1856, 3 (3): 41.

${ }^{2}$ Thomas Oliver, 'Indiarubber: danger incidental to the use of bisulphide of carbon and naptha', in Thomas Oliver (ed.), Dangerous trades, London, John Murray, 1902, p. 472.

${ }^{3}$ For example, in Europe in 1976, solvent use in paints alone was estimated at 1.8 million tonnes. Figures for various types of solvent usage during the 1970s and 1980s in the European Union can be
} 


\section{Anne Spurgeon}

daily basis. ${ }^{4}$ The neurotoxic properties of these substances were well-known and, although few solvents were as dramatically hazardous as carbon disulphide, several others, including those routinely contained in paints and varnishes, produced unpleasant symptoms of dizziness, nausea and fatigue. It was generally accepted, however, that these less severe effects of intoxication were essentially acute responses to short periods of high exposure. Although undesirable, such symptoms rapidly reversed when exposure ceased, and were assumed to cause no permanent damage to the nervous system. ${ }^{5}$

This opinion remained largely unchallenged during the first half of the twentieth century and thus industrial hygiene policies focused on the installation of ventilation systems to prevent the occurrence of these disagreeable but essentially transient effects. In the early 1960s, however, a new hypothesis about the potential dangers of solvent exposure began to emerge. ${ }^{6}$ It was suggested that the inhalation of low levels of solvents over a number of years could insidiously and progressively damage the brain, giving rise to mental health problems and adverse effects on intellectual functioning. The name given to this newly identified occupational disease was "organic solvent syndrome". 7 A particularly innovative feature from the point of view of occupational medicine was that diagnosis of the condition required the use of psychological performance tests. Such tests, it was argued, were able to detect the disease in its early stages by identifying very small changes in cognitive functioning. During the next thirty years, this disease and its accompanying diagnostic methodology gained wide international acceptance resulting in radical changes to regulatory controls on the industrial use of solvents in many countries. In western Europe, thousands of workers were diagnosed with the condition and were awarded disability pensions and financial compensation. ${ }^{8}$

However, throughout the period when organic solvent syndrome was rapidly diffusing across the world, there emerged one prominent group of dissenters from the consensus view. In Britain, scientists and physicians involved in the development of occupational health and safety legislation continued to question the reality of the disease, maintaining a deep suspicion that organic solvent syndrome was an entirely fictitious condition, depending for its existence on unscientific techniques of diagnosis and dubious data. Moreover, scientific and medical scepticism in the UK was matched by apparent indifference on the part of workers and workers' organizations, who seemed largely unconcerned about this new hazard in their midst. The subject received virtually no media attention and barely

found in Solvents in common use: health risks to workers, Publication No. Eur 11553 of the CEC Scientific and Technical Communication Unit, Report prepared by the Royal Society of Chemistry for the CEC, Brussels-Luxembourg, CEC, 1988, p. 6. In 1984 approximately 49 million tons of industrial solvents were produced in the United States. Figures from NIOSH Current Intelligence Bulletin 48: Organic solvent neurotoxicity, US Centers for Disease Control, National Institute for Occupational Safety and Health, Cincinnati, 31 Mar. 1987, p. 2.

${ }^{4}$ In 1987 it was estimated that approximately 9.8 million workers in the US alone were potentially exposed to solvents. Ibid., NIOSH Current Intelligence Bulletin 48, p. 1.
${ }^{5}$ Ethel Browning, Toxicity of industrial organic solvents, London, HMSO, 1953, p. 78.

${ }^{6}$ Helena Hanninen, 'Psychische symptome bei schwefelkohlen-stoffvergiftung', in XIVth International Congress on Occupational Health, International Congress Series, No. 62, Amsterdam, Excerpta Medica Foundation, 1964, vol. 2, pp. 894-7.

${ }^{7}$ The name by which it is most commonly known, although it has different names in different countries, for example, "toxic solvent syndrome" and "psychoorganic syndrome", and "solvent related chronic toxic encephalopathy".

${ }^{8}$ G Triebig and J Hallermann, 'Survey of solventrelated encephalopathy as an occupational disease in European countries', Occup. Environ. Med., 2001, 58: 575-81. 


\section{Organic Solvent Syndrome in late-Twentieth-Century Britain}

registered on the public consciousness, in marked contrast to the situation in other parts of the world. Although recognition of organic solvent syndrome was by no means universal, official and unofficial attitudes in the UK represented probably the strongest example of the wholescale rejection of the disease and its diagnostic methodology. This is particularly interesting when one considers the progressive harmonization of other aspects of occupational health and safety regulation taking place within the European Union at the time.

It has been observed that occupational diseases can assume different levels of acceptance and importance in different environments, despite those environments having similar levels of exposure to the hazard in question, similar levels of educational and social development and access to the same scientific information. ${ }^{9}$ Thus, in terms of their potential for social construction, it would seem that occupational diseases are no different from other diseases. The recognition of a new medical condition, or innovative technique for its diagnosis, may depend less on any supposedly objective appraisal of the scientific evidence and more on the interplay of various social, cultural and professional influences operating in different places at different times. ${ }^{10}$ However, because work-related diseases emerge within the context of employment, an examination of the possible reasons for their rise and fall requires consideration of some features additional to those which tend to be invoked to explain the progress of many community-based epidemics. The motives and activities of legislators and policymakers, the operation of contemporary systems of compensation and the attitudes of employers, workers and trades unions may all have a role to play in the recognition of an occupational disease. ${ }^{11}$ Organic solvent syndrome was a neurological condition which manifestly failed to thrive in one environment while flourishing in another, and, as such, provides an opportunity to explore some of these factors in a late-twentieth-century setting. The remainder of this paper, therefore, will examine the reasons for the British rejection of this occupational disease, focusing particularly on the attitudes of scientists and physicians towards its method of diagnosis and how these attitudes were developed and maintained within the context of traditional approaches to health and safety regulation in the UK.

\section{The Rise of Organic Solvent Syndrome}

In the early 1960s Helena Hanninen, an occupational psychologist employed at the National Institute of Occupational Health in Helsinki, noted that a number of men employed in Finland's viscose rayon industry had been referred to her with suspected carbon disulphide poisoning. ${ }^{12}$ These workers showed symptoms of anxiety and depression and seemed to suffer from mood swings and difficulties with memory and concentration. However, although in some ways their symptoms were reminiscent of those of the

\footnotetext{
${ }^{9}$ Allard Dembe, Occupation and disease: how social factors affect the conception of work-related disorders, New Haven and London, Yale University Press, 1996, pp. 1-3.

${ }^{10}$ As discussed by Charles E Rosenberg, Explaining epidemics and other studies in the history of medicine, Cambridge University Press, 1992, pp. 305-18; John Pickstone 'Introduction', in idem (ed.), Medical innovations in historical perspectives,
}

Basingstoke, Macmillan Academic and Professional, 1992, pp. 1-16; Jennifer Stanton 'Introduction: On theory and practice', in idem (ed.), Innovations in health and medicine, London and New York, Routledge, 2002, pp. 1-18.

${ }^{11}$ Dembe, op. cit., note 9 above, pp. 229-58.

${ }^{12} \mathrm{H}$ Hanninen, 'Twenty-five years of behavioral toxicology within occupational medicine: a personal account', Am. J. Ind. Med., 1985, 7: 19-30. 


\section{Anne Spurgeon}

early rubber manufacturers, the problems of these Finnish workers were much less severe than those encountered in the nineteenth century. Moreover, their condition did not appear to be an acute response to short-term high exposure, but rather to have developed gradually over a number of years. Many of these workers, for example, had worked at the factory for more than twenty years and their difficulties had only recently come to light. The cause of their problems seemed difficult to establish. In 1963, Hanninen prepared a case series and presented a paper to the XIVth International Congress of Occupational Health in Madrid ${ }^{13}$ in which she suggested the possibility of a new occupational disease, a disorder of the nervous system called "psycho-organic syndrome" or "organic solvent syndrome". 14 This condition, she proposed, might result from cumulative exposure to relatively low concentrations of solvents, occurring over a number of years.

Although Hanninen was concerned primarily with industrial hazards, her ideas emerged against a background of growing international anxiety about pollution in the wider environment and the ensuing threat to public health. Rachel Carson's Silent spring, published in $1962,{ }^{15}$ had been hugely influential in raising public consciousness, both in the United States and in Europe, about the potential dangers associated with the widespread use of chemicals in industry and agriculture. In her section on human health Carson proposed that the repeated absorption of small amounts of chemical substances over a period of time might result in ill-health many years later. The biological effects of chemicals, she argued, were cumulative and thus "the hazard to the individual may depend on the sum of exposures received throughout his lifetime". ${ }^{16}$ She referred specifically to the delayed neurotoxic effects of some chlorinated hydrocarbons "loss of memory, insomnia, and nightmares to mania". ${ }^{17}$ Hanninen's hypothesis about the potential dangers of longterm, low-level solvent exposure, first proposed a year after the publication of Silent spring, were clearly in tune with these growing environmental concerns.

The origins of twentieth-century environmentalism have been traced, in part, to the earlier recognition of industrial hazards, with the theories and methods of occupational medicine providing a basis for the new science of environmental health. ${ }^{18}$ During the second half of the twentieth century, however, this influence often appeared to flow in the reverse direction, such that environmental findings frequently triggered new occupational concerns. Although the long latency periods associated with some occupational carcinogens had been recognized for many years, ${ }^{19}$ certain other workplace chemicals, previously considered only in terms of their potential to act as acute poisons, were now suspected of operating gradually and insidiously, at low doses, to produce disease many years later. This occurred particularly in the field of neurotoxicity where there was a reappraisal of the occupational risks associated, not only with organic solvents, but also with metals such as lead and mercury. ${ }^{20}$ Since environmental exposures tended to be much lower than those

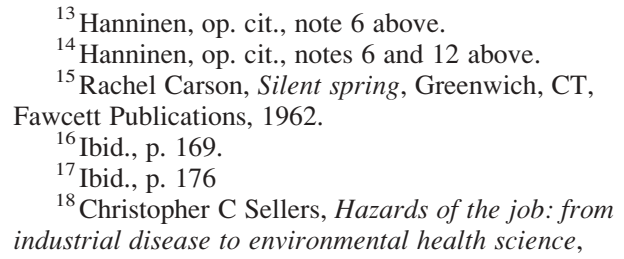

Chapel Hill and London, University of North Carolina Press, 1997, pp. 227-40.

${ }^{19} \mathrm{See}$, for example, the section on 'Occupational Cancer' in Donald Hunter's The diseases of occupations, 5th ed., London, English Universities Press, 1975, pp. 774-92.

${ }^{20}$ Behavioural research on low-level exposures in the workplace was discussed at governmental level in 


\section{Organic Solvent Syndrome in late-Twentieth-Century Britain}

routinely encountered in the workplace it was difficult to ignore the possibility that workers might be equally, if not more, vulnerable to the effects of neurotoxic chemicals. ${ }^{21}$ Accompanying these concerns were new debates about the validity of clinical signs as indicators of ill-health. ${ }^{22}$ There were suggestions that these might be effective in diagnosing only more advanced forms of disease and that earlier effects might be identified by the use of other more sensitive methods. In North America these debates were taking place, in particular, in the context of the campaign to reduce environmental lead exposure and researchers were beginning to use neurophysiological techniques, such as nerve conduction, to support their claims of "sub-clinical effects". ${ }^{23}$ Hanninen, by contrast, turned to the tools of her own trade to address these sorts of questions and began to use psychological performance tests to measure aspects of intellectual functioning such as memory and learning ability, concentration and information processing. She argued that these tests provided a means of identifying effects which were less obvious than the symptoms of "insanity" observed in those with severe poisoning, but which provided important early warning signs of disease. ${ }^{24}$

Psychological tests were not new, having been used in educational and clinical settings for many years, as well as in industrial psychology to determine the limits of physical and mental endurance imposed by fatigue and stress. ${ }^{25}$ However, their use within occupational medicine to assess neurotoxicity represented a new departure. Although Hanninen reported that her initial reception in Madrid was somewhat muted, other occupational psychologists in Europe and in the United States rapidly became interested in her work and began to experiment with these techniques. During the 1970s and 1980s they were adopted by a number of investigators working in both occupational and environmental health research. ${ }^{26}$ In 1971, for example, Herbert Needleman published his controversial claims that

the US for the first time at a meeting of the National Institute for Occupational Safety \& Health (NIOSH) in 1974. See C Xintaras, B L Johnson and I de Groot (eds), Behavioral toxicology: early detection of occupational hazards, NIOSH Publication No. 74-126, Washington, NIOSH, 1974; J D Repko, B B Morgan and

$\mathrm{J}$ A Nicholson, Behavioral effects of occupational exposure to lead, HEW publication, no. (NIOSH) 75-164, Cincinnati, Ohio, US Dept. of Health, Education, and Welfare, Public Health Service, Center for Disease Control, NIOSH, 1975; D B Chaffin, B D Dinman, J M Miller, R G Smith, and D H Zontine, An evaluation of the effects of chronic mercury exposures on EMG and psychomotor functions, HSM 099-71-62, Washington, DC, US Dept. of Health Education and Welfare, NIOSH, 1973.

${ }^{21}$ W Kent Anger, 'Workplace exposures', in Z Annau (ed.), Neurobehavioral toxicology, London, Edward Arnold, 1986, pp. 331-7, on pp. 331-4.

${ }^{22} \mathrm{C}$ Xintaras and B L Johnson, 'Behavioral toxicology: early warning and worker safety and health', in Wayland J Hayes Jr (ed.), Essays in toxicology, vol. 7, New York, Academic Press, 1976, pp. 155-201.
${ }^{23} \mathrm{G}$ Markowitz and D Rosner, Deceit and denial: the deadly politics of industrial pollution, Berkeley, University of California Press, 2002, p. 122.

${ }^{24} \mathrm{H}$ Hanninen, 'Psychological picture of manifest and latent carbon disulphide poisoning', $B r$. J. Ind. Med., 1971, 28: 374-81.

${ }^{25}$ Tests of intellectual functioning, used in Britain, originated in the psychometric work of Francis Galton. Francis Galton, Inquiries into human faculty and its development, London, Macmillan, 1883; see also G C Bunn, 'Introduction', in G C Bunn, A D Lovie and G D Richards (eds), Psychology in Britain: historical essays and personal reflections, Leicester, BPS Books, 2001, pp. 1-29, on p. 2. Use of tests in British occupational psychology began during the First World War to investigate industrial fatigue in munitions workers, with the aim of maximizing production, see Ministry of Munitions, Industrial fatigue and its causes, Health of Munitions Workers Committee, Memorandum No. 7, London, HMSO, 1916; see also Sylvia Shimmin and Don Wallis, Fifty years of occupational psychology in Britain, Leicester, BPS Books, 1994, pp. 3-10.

${ }^{26}$ For a summary of neurobehavioural studies carried out in North America and Europe during the 


\section{Anne Spurgeon}

environmental exposure to lead was adversely affecting the intellectual functioning of thousands of children in the United States. ${ }^{27} \mathrm{~A}$ few years later cognitive function tests were adopted to study the effects of pesticide exposure on agricultural workers ${ }^{28}$ and to explore the developmental consequences of prenatal exposure to methylmercury in countries where maternal diets were rich in seafood. ${ }^{29}$

In the years immediately following the Madrid Congress, researchers at the Finnish Institute carried out further studies of men exposed to carbon disulphide and began to extend their research to include workers exposed to other less toxic solvents such as those contained in paints and varnishes. ${ }^{30}$ They also developed and refined a standard set of tests (a "test battery") for use by occupational health practitioners. ${ }^{31}$ During the 1970s, psychologists in several other countries in western Europe and in the United States began to carry out their own research into organic solvent syndrome and to develop their own test batteries. ${ }^{32}$ By 1980 interest in the subject, which had by this stage acquired the title "neurobehavioural toxicology", was spreading to other parts of the world, and in 1982 the first large international conference on 'Neurobehavioural Methods in Occupational Health' was held in Milan. Between 1970 and 1990 more than forty research studies were published which used neurobehavioural methods to determine the effects of longterm occupational exposure to solvents. ${ }^{33}$

The results of these investigations, carried out in a range of culturally diverse countries spanning Europe, Asia, Australasia and the Americas, were regarded by many scientists and physicians working in the field as highly consistent in confirming the existence of organic solvent syndrome. ${ }^{34}$ Workers who were apparently at risk of this disease included, in particular, housepainters and spray painters, but also printers, floor-layers, boat builders, dockyard and construction workers, and dry cleaners. Essentially, the disease was said to be characterized by disturbances of mood and personality and impairments of cognitive functioning. At its most severe it resembled a form of senile dementia. Diagnosis involved neurobehavioural testing and required an assessment of the duration of solvent exposure. It

1970s and early 1980s, see Robert B Dick and Barry L Johnson, 'Human experimental studies', in Z Annau (ed.), op. cit., note 21 above, pp. 348-87.

${ }^{27}$ Herbert L Needleman, 'Epidemiological studies', in Z Annau (ed.), op. cit., note 21 above, pp. 279-87, on pp. 282-5.

${ }^{28}$ R L Rodnitzky, L S Harvey and L M David, 'Occupational exposure to organophosphate pesticides: a neurobehavioral study', Arch. Environ. Health, 1975, 30 (2): 98-103.

${ }^{29} \mathrm{~K}$ S Crump, T Kjellstrom, A M Shipp, A Silvers, A Stewart, 'Influence of prenatal mercury exposure upon scholastic and psychological test performance: benchmark analysis of a New Zealand cohort', Risk Analysis, 1998, 18 (6): 701-13. This longitudinal study began in 1977 .

${ }^{30}$ Hanninen, op. cit., note 24 above; H Hanninen, L Eskelinen, K Husman and M Nurminen, 'Behavioral effects of long-term exposure to a mixture of organic solvents', Scand. J. Work Environ. Health, 1976, 2 (4): 240-55; K Lindstrom, 'Changes in psychological performances of solvent-poisoned and solvent-exposed workers', Am. J. Ind. Med., 1980, 1: 69-84.

${ }^{31} \mathrm{H}$ Hanninen, 'Psychological test batteries: new trends and developments', in R Gilioli, M G Cassitto, V Foà (eds), Neurobehavioral methods in occupational health, Oxford, Pergamon Press, 1983, pp. 123-9.

${ }^{32} \mathrm{~F}$ Gamberale, 'Behavioral effects of exposure to solvents: experimental and field studies', in M Horváth (ed.), Adverse effects of environmental chemicals and psychotropic drugs. Vol. 2: Neurophysiological and behavioral tests, Amsterdam, Elsevier, 1976, pp. 111-34; M G Cassito, 'Current behavioural techniques', in Gilioli, Cassito, Foà (eds), op. cit., note 31 above, pp. 27-38.

${ }^{33}$ A Spurgeon, The validity and interpretation of neurobehavioural data obtained in studies to investigate the neurotoxic effects of occupational exposure to mixtures of organic solvents, HSE Contract Research Report. 355/2001, Sudbury, Suffolk, HSE Books, 2001, pp. 7-8.

${ }^{34}$ Ibid., pp. $17-18$. 


\section{Organic Solvent Syndrome in late-Twentieth-Century Britain}

was generally agreed that at least ten years of exposure were required to produce the condition. ${ }^{35}$

In 1976, Denmark became the first country officially to recognize the existence of the disease (although adopting the name "solvent-related chronic toxic encephalopathy"), and began providing compensation for affected workers. Over the subsequent decade, many other countries followed its example and thousands of cases began to be reported. ${ }^{36}$ Although local circumstances determined to some extent the enthusiasm with which the disease was embraced in different countries, ${ }^{37}$ by the early $1990 \mathrm{~s}$, most in western Europe, and many others worldwide, had formally or informally signalled broad acceptance of the condition and its cause. ${ }^{38}$ In 1999, the chairman of the VIIth International Symposium on Neurobehavioural Methods, reflecting on past achievements, remarked that it was "incredible to believe that fifteen years ago we were still discussing whether organic solvent syndrome actually existed". ${ }^{39}$ The size of this conference, attended by more than 300 delegates from forty countries, attested to the growing popularity of the subject and its establishment, by the end of the century, as a major field of scientific endeavour.

\section{Organic Solvent Syndrome in Britain}

Organic solvent syndrome first came to the notice of occupational health physicians in Britain in the early 1970s. The Scandinavian findings were prominent among the topics discussed at meetings of the International Committee on Occupational Health (ICOH) around this period, and papers on the subject were beginning to appear in the scientific literature. ${ }^{40}$ In 1977, a group of doctors who were studying for their Diploma in Industrial Health at the London School of Hygiene and Tropical Medicine (LSHTM) visited a factory where one particular solvent, styrene, was used in the production of reinforced plastics. ${ }^{41}$ They were accompanied by a doctor from the Health and Safety Executive's newly-formed Employment Medical Advisory Service (EMAS) who, having noted some concerns amongst the workers about the possible effects of styrene on their health, suggested that the LSHTM might carry out some research. ${ }^{42}$ Fortuitously, the LSHTM was ideally placed to carry out a neurobehavioural study at that time, having just appointed an

\footnotetext{
${ }^{35}$ Similar (although not exactly the same) diagnostic criteria were agreed at two international workshops held in 1985. WHO/Nordic Council of Ministers Working Group, Chronic effects of organic solvents on the central nervous system and diagnostic criteria, Copenhagen, WHO, 1985; E L Baker and A M Seppalainen, 'Human aspects of solvent neurobehavioral effects: report of the workshop session on clinical and epidemiological topics, Raleigh, North Carolina 1985', Neurotoxicology. 1986, 7: 43-56.

${ }^{36}$ Triebig and Hallermann, op. cit., note 8 above, p. 577.

${ }^{37}$ For a discussion of the political context in Denmark, one of the prime movers in the promotion of organic solvent syndrome, see M Johansson and T Partanen, 'Role of trade unions in workplace health promotion', Int. J. Health Serv., 2002, 32 (1): 179-93. p. 576.
}

\footnotetext{
${ }^{39}$ Personal communication, conference delegate.

${ }^{40}$ Hanninen, op. cit., note 24 above; Lindstrom, op. cit., note 30 above; O Axelson, M Hane and C Hogstedt, 'A case-referent study on neuropsychiatric disorders among workers exposed to solvents', Scand. J. Work Eviron. Health, 1976, 2: 14-20; H Hanninen, L Eskelinen, K Husman and M Nurminen, 'Behavioral effects of long-term exposure to a mixture of organic solvents', Scand. J. Work Environ. Health, 1976, 2: 240-55; M Hane, O Axelson, J Blume, C Hogstedt, et al., 'Psychological function changes among house painters', Scand. J. Work Environ. Health, 1977, 3: 91-9.

${ }^{41}$ Personal communication, occupational psychologist at LSHTM.

${ }^{42}$ EMAS was formed in 1973 to conduct research and medical investigations. It was a successor to the Medical Services Division of the Department of Employment and published its first report in 1975.
} 


\section{Anne Spurgeon}

occupational psychologist to its staff. In 1978, therefore, the first neurobehavioural study of the effects of solvent exposure was carried out in the UK. ${ }^{43}$ This study was not, in fact, concerned with organic solvent syndrome in the sense that the disease was already understood in other parts of Europe, but rather with measuring short-term, reversible effects of styrene exposure. However, it undoubtedly marked the advent of neurobehavioural toxicology in the UK, using, for example, some tests derived from clinical neuropsychology to determine the extent to which workers' intellectual processes were impaired by recent exposure to solvents. Further studies soon followed, exploring the possibility that permanent brain damage might occur as a result of the cumulative effects of many years of exposure. In particular, in 1981, Thomas Pace, a postgraduate student at LSHTM, carried out an investigation of workers with long-term exposure to paint solvents. ${ }^{44}$

Thus far the pattern of investigation in the UK could be said to have closely followed that of many other countries in western Europe. Occupational physicians and the regulatory authorities had been alerted to a possible problem and a respected academic department had carried out research. The results of the UK studies, however, were regarded as much less conclusive than those carried out in other parts of the world. Although there were some positive findings, it was argued that these could be explained by factors unconnected with solvent exposure. At best, the results were seen as suggesting the need for further research, but were hardly proof of the existence of an important new disease, nor did they imply the need for urgent regulatory action. Unlike the majority of other countries, therefore, which moved steadily towards official recognition of the organic solvent syndrome, the UK adopted a stance that could best be described as a watching brief.

The first obvious demonstration of this position occurred in 1982 when the Health and Safety Executive (HSE) and academics from the LSHTM arranged a symposium to discuss the subject. ${ }^{45}$ There was growing unease amongst those UK industries likely to be most affected by stricter controls on the use of solvents. These included some large and influential companies, like ICI, who had substantial paint-making and pharmaceutical divisions, the oil giant BP, and also Courtaulds, which made viscose rayon. Delegates to the symposium, therefore, included representatives from these and other industries, together with researchers from Finland, Sweden, Denmark and the United States, who came to present and discuss their data. In the course of discussion it became clear that the HSE representatives were sceptical about neurobehavioural tests as a method of diagnosis and were inclined to believe that the reported effects of long-term, low-level solvent exposure, even if real, were too small to merit serious consideration as indicators of ill-health. The HSE's Director of Medical Services, for example, noted the difficulty in accepting results based on psychological testing among "those of us trained in the more physical school", adding that this was an attitude that had to be faced "until more objective measures were

\footnotetext{
Employment and Medical Advisory Service: a report of the work of the Service for 1973 and 1974, London, HMSO, 1975.

${ }^{43}$ N Cherry, B Rodgers, H Venables, HA Waldron, G G Wells, 'Acute behavioural effects of styrene exposure: further analysis', Br. J. Ind. Med., 1981, 38: $346-50$.

${ }^{44} \mathrm{~N}$ Cherry, H Hutchins, T Pace and H A Waldron, 'Neurobehavioural effects of repeated occupational
}

exposure to toluene and paint solvents', $B r$. J. Ind . Med., 1985, 42 (5): 291-300.

${ }^{45} \mathrm{~N}$ Cherry and $\mathrm{H}$ A Waldron (eds), The neuropsychological effects of solvent exposure: proceedings of a symposium held at the London School of Hygiene and Tropical Medicine 5-6 Apr. 1982, Havant, Hants, Colt Foundation, 1983. 


\section{Organic Solvent Syndrome in late-Twentieth-Century Britain}

available". ${ }^{46}$ It seemed that psychological methods were regarded as only a temporary measure, to be used until something more scientific came along. These misgivings appeared to lie at the heart of official reluctance to acknowledge a condition like organic solvent syndrome.

A number of recent social histories of occupational health have illuminated the complex and protracted debates which often precede the regulation and control of an industrial hazard. ${ }^{47}$ The specific content of these debates reflects the differing social, political and economic agendas of the interested parties and accordingly varies with the hazard in question. However, two underlying issues are common to all, namely the recognition of the disease as a separate entity with its own diagnostic criteria, and the establishment of a relationship between that disease and a particular occupational exposure. These issues are rarely straightforward, even where a condition has obvious pathological manifestations and such uncertainties have often been exploited by different groups for their own purposes. During the 1930s, for example, arguments about the nature of lung disease in quarrymen revolved around the question of the distinction between silicosis and tuberculosis and hence the specifically occupational nature of the disease. ${ }^{48}$ Similar arguments occurred in relation to pneumoconiosis in coal miners where, in addition, the nature of the particular dust involved as the causal agent was a further source of dispute and hence delay. ${ }^{49}$ In these cases, however, the physical reality of the disease was ultimately demonstrable by methods accepted as objective by the medical and scientific community. Thus their stories, however protracted, tend to conclude with disease recognition, regulation and perhaps compensation. Organic solvent syndrome, by contrast, was an illness consisting of ill-defined symptoms of general malaise, accompanied by impairment of performance on subjective psychological tests. As such it was surrounded by additional uncertainties and encountered barriers to acceptance which served to underline some particular features of British regulatory attitudes towards industrial disease.

Illnesses of questionable organic origin, which emerge at intervals in the wider community, have often been the subject of historical enquiry. ${ }^{50}$ However, the occurrence of such conditions in an occupational context has received much less attention. Allard Dembe's discussion of the upsurge of cumulative trauma disorders (CTDs) in North American workplaces during the 1970s and 1980s, provides a rare example of the examination of a group of occupationally-related conditions for which there was no demonstrable pathology. In describing the path towards official recognition of these conditions Dembe notes that, by the 1980s, the inability of American scientists and doctors to uncover a specific pathological lesion to explain a disorder no longer created a barrier to medical

\footnotetext{
${ }^{46}$ Ibid., p. 26.

${ }^{47}$ See, for example, A Derickson. Black lung: anatomy of a public health disaster, Ithaca and London, Cornell University Press, 1998; Geoffrey Tweedale, Magic mineral to killer dust: Turner \& Newall and the asbestos hazard, Oxford University Press, 2000; Christian Warren, Brush with death: a social history of lead poisoning, Baltimore, John Hopkins University Press, 2000; R Bayer, 'Coal, lead, asbestos and HIV: the politics of regulating risk', J. Occup. Med., 1993, 35 (9): 898-901.
} 


\section{Anne Spurgeon}

acceptance. ${ }^{51}$ Dembe attributes this change in attitude to the rise of epidemiological methods which, unlike laboratory investigations, emphasized the importance of identifying increased risks at group level rather than focusing on individual cases. However, this seems incomplete as an explanation. Epidemiological methods were also well advanced in Britain at the time having acquired a central role in occupational health research as early as the $1950 \mathrm{~s},{ }^{52}$ yet the requirement for demonstrable pathology remained. Moreover, the epidemiological approach in no way obviated the need for case definition. In North America, unlike Britain, however, there developed an acceptance of the use of psychological or, more broadly, self-report methods, to achieve that definition, at least in terms of compensable disease. ${ }^{53}$

British reluctance to embrace psychological methods in occupational health can be traced, in part, to the early stages of industrial disease notification and compensation in the UK, beginning with the Factory and Workshop Act of 1895. This required the notification to the Factory Inspectorate of four specific diseases (extended to five in 1899), all of which were characterized by well-established features of poisoning. ${ }^{54}$ The Worker's Compensation Act of 1897 established the principle of "no fault" compensation for the first time, but only in respect of industrial accidents, not disease. ${ }^{55}$ The subsequent Act of 1906, however, extended this to the five notifiable diseases plus one other. ${ }^{56}$ The fact that disease compensation grew out of accident compensation had important consequences for subsequent approaches to health and safety regulation in the UK. Tim Carter, in his discussion of the speed of regulation of different occupational diseases in the first quarter of the twentieth century, notes that specific and physically identifiable diagnostic features, and an understanding and acceptance of the relationship between exposure and response were always important prerequisites for disease recognition. ${ }^{57}$ Further, he observes that the adoption of certain disease conventions, particularly notification to the Factory Inspectorate, has played an important part in framing British perceptions and definitions of industrial disease. Subsequently these early regulatory requirements softened to some extent, with the recognition that many diseases had multiple possible causes. ${ }^{58}$ Thus the demonstration of a relationship between a certain condition and a particular hazard became

\footnotetext{
${ }^{51}$ Dembe, op. cit., note 9 above, p. 99.

${ }^{52}$ Richard Schilling, A challenging life: sixty years in occupational health, London, Canning Press, 1998, pp. 69-80.

${ }^{53}$ British physicians have increasingly emphasized the predominance of psychosocial over physical factors in the development and maintenance of musculoskeletal disorders. This has been suggested as a factor in the significant reduction, since 1995, in awards of social security benefits for such conditions. See, J M Harrington, J Hancock, D Gompertz, A Spurgeon, 'Work-related upper limb pain syndromes - origins and management', Report on a research priorities workshop, hosted by the University of Birmingham, sponsored by the HSE, 1011 October, 1995, pp. 8-11, http://www.hse.gov.uk/ research/misc/harrington.pdf; Also, G Waddell, M Aylward and P Sawney, Back pain, incapacity for work and social security benefits, London, Royal Society of Medicine Press, 2002, pp. 183-5.
}

\footnotetext{
${ }^{54}$ Deriving from the recommendations of the Dangerous Trades Committees of the 1880s, these diseases were arsenic, lead and phosphorus poisoning, and anthrax. In 1899 mercury poisoning was added.

${ }^{55}$ This exception was anthrax (occurring in the woollen industries), which was established in a landmark case when the House of Lords ruled that the features of the disease (i.e. rapid and fatal, with little doubt of causation) were sufficient for it to be classified as an accident for the purposes of compensation. Brintons Ltd $v$ Turvey, AC 230, 14 April 1905.

${ }^{56}$ Ankylostomiasis, a form of hookworm which occurred in Cornish tin miners.

${ }^{57}$ Tim Carter, 'The biology of occupational disease and the pace of prevention: an historical study of UK control measures', Policy and Practice in Health and Safety, 2003, 1 (2): 83-96.

${ }^{58}$ See Roy Porter's The greatest benefit to mankind: a medical history of humanity from Antiquity to the present, London, HarperCollins, 1997, p. 576, for
} 


\section{Organic Solvent Syndrome in late-Twentieth-Century Britain}

couched in terms of probabilities and the magnitude of risk. ${ }^{59}$ However, the requirement for a set of well-defined diagnostic criteria, preferably including observable pathology and an understanding of the mechanism underlying the exposure-response relationship, remained.

Against this background, the toxicity of industrial chemicals has traditionally been the concern of the Hazardous Substances Division of the HSE, a division peopled largely by inspectors, technical specialists and administrators with scientific support from toxicologists and epidemiologists. The HSE's lack of enthusiasm for neurobehavioural data needs to be understood in the context of these disciplinary constraints. Few, if any, of these groups were likely to be comfortable with neurobehavioural toxicology, which was in many ways an imprecise science, inconsistent in terms of defining the nature of a disease or its prognosis, and incapable of linking the outward manifestations of the syndrome to any internal bodily processes. The nature of psychological testing was such that a large number of seemingly uncontrolled factors, many of which were unconnected to conditions in the workplace, were present in any investigation. ${ }^{60}$ Moreover, the heavy reliance on the performance of the workers themselves in the definition of their illness raised suspicions about their possible motivation. How could one be sure that some workers might not fake poor results in order to gain compensation?

Those physicians involved in the process of health and safety regulation, working alongside scientists on government advisory committees, were predominantly employed in the private sector, often by large companies. Clearly this factor may have influenced their opinions and created conflicts of interest. However, their attitudes should also be viewed in the context of their initial training, which would largely have taken place within the National Health Service. A system of free healthcare, constrained by limited time and resources, tends to discourage interest in illnesses of doubtful physical veracity, and sceptical attitudes are likely to harden where issues of compensation are involved. The importance of precise definition with observable diagnostic markers was further reinforced in British medicine during the latter part of the twentieth century when increasing demands on the health service stimulated a requirement for all clinical practice to be based on strong scientific evidence. In 1972 the British occupational epidemiologist Archie Cochrane published his seminal work on effectiveness and efficiency in the health services, marking the beginning of evidence-based medicine in the UK. ${ }^{61}$ Cochrane emphasized the importance of systematic scientific evaluation of all forms of healthcare, to ensure cost-effective use of limited resources. The approach was originally targeted at the needs of clinical

the discovery of various cancer-causing agents during the early twentieth century; pp. 579-80, for the recognition of the contribution of smoking to lung cancer by Bradford-Hill and Doll in 1951; pp. 585-6, for the understanding of various contributors to coronary heart disease following the identification of cholesterol by Brown and Goldstein in the late 1960s.

${ }^{59} \mathrm{~J}$ Malcolm Harrington, 'Compensation schemes for industrial injuries and diseases', in P J Baxter, P H Adams, T-C Aw, A Cockcroft and J M Harrington (eds), Hunter's diseases of occupations, 9th ed., London, Arnold, 2000, pp. 37-42.

\footnotetext{
${ }^{60}$ For a discussion of these factors, see University of Birmingham, Institute of Occupational Health, Occupational exposure limits: criteria for the qualitative evaluation of human neurobehavioural studies of neurotoxicity, European Commission, Employment and Social Affairs, Health and Safety at Work series, Report EUR 17390 EN, Luxembourg, Office for Official Publications of the European Communities, 1997, pp. 22-3.

${ }^{61}$ A L Cochrane, Effectiveness and efficiency: random reflections on health services, London, Nuffield Provincial Hospitals Trust, 1972.
} 


\section{Anne Spurgeon}

medicine, but during the last quarter of the century it was adopted in numerous other fields of healthcare. In a series of articles published during the late 1960s, Cochrane also addressed the question of health screening, urging the establishment of high levels of specificity and sensitivity for all techniques before their widespread adoption. ${ }^{62}$ The claims of the neurobehavioural toxicologists, who argued that their tests provided early identification of subtle neurotoxic effects, undoubtedly encountered more stringent scrutiny than would have been the case before the evidence-based revolution.

The British regulatory authorities thus had numerous difficulties with organic solvent syndrome. Their response was to embark upon a process of procrastination culminating in a form of passive acceptance which conceded tighter controls on solvents without formal recognition of the disease. The final report of the 1982 symposium, which was undoubtedly received with some relief by interested industries, set the tone for British policy on this subject for the next twenty years. It contained the statement that "the current evidence was insufficient to convince British policymakers of the need for a review of existing occupational exposure standards". ${ }^{63}$ However, "there appeared to be a need for more research", 64 This traditional form of delay, often adopted in the face of uncertainty, presumably represented an equally satisfactory conclusion for those British researchers present. Whether it was intended that such research should involve the use of psychological methods was left open to question and certainly no such research was commissioned until five years later. ${ }^{65}$

In the early 1980s while the number of cases of organic solvent syndrome continued to rise in the rest of Europe, the tally in the UK remained at zero. ${ }^{66}$ In 1985 , when two international meetings were held in Copenhagen and the United States to discuss diagnostic criteria for the disease, the HSE and the major British chemical and oil industries sent along medical and scientific representatives. ${ }^{67}$ Their status, however, was largely that of observers since, as one HSE representative remarked, it was difficult to argue with descriptions of clinical cases when there had been no such reported cases in the UK. ${ }^{68}$

An important factor which deserves some explanation here is the silence of the British trade unions on the subject of organic solvent syndrome. Dembe notes that in North America CTDs would not have achieved their impact during the 1980s without the concerted efforts of organized labour. However, historians of twentieth-century work and health in Britain have tended to present the trade unions as relatively minor players in the process of health and safety regulation. ${ }^{69}$ After the 1970 s their disengagement with such

\footnotetext{
${ }^{62}$ A L Cochrane, 'A medical scientist's view of screening', Public Health, 1967, 81: 207-13; A L Cochrane and P C Elwood, 'Screening - the case against it', Medical Officer, 1969, 71: 53-7. By the late 1960 s Cochrane was already renowned for his epidemiological research on pneumoconiosis in Welsh miners, which he had begun in the 1940s.

${ }^{63}$ Cherry and Waldron (eds), op. cit., note 45 above, p. 28 .

${ }^{64}$ Ibid., p. 28.

${ }^{65}$ In the autumn of 1987 the HSE awarded a contract to the University of Birmingham to investigate the neurobehavioural effects of long-term exposure to organic solvents. A Spurgeon, C N Gray, J Sims,
}

I A Calvert, et al., 'Neurobehavioral effects of longterm occupational exposure to organic solvents: two comparable studies', Am. J. Ind Med., 1992, 22: 325-35.

${ }^{66}$ Triebig and Hallermann, op. cit., note 8 above, p. 576.

${ }^{67}$ WHO/Nordic Council of Ministers, op. cit., note 35 above; Baker and Seppalainen, op. cit., note 35 above.

${ }^{68}$ Personal communication. Director of Medical Services, HSE.

${ }^{69} \mathrm{~S}$ Bowden and G Tweedale, 'Mondays without dread: the trade union response to byssinosis in the Lancashire cotton industry in the twentieth century', 


\section{Organic Solvent Syndrome in late-Twentieth-Century Britain}

issues seems to have been particularly pronounced. Labour relations in Britain during the 1970s were characterized by major ideological conflicts between different factions of the union movement. The Health and Safety at Work Act of 1974 provided trade unions with equal representation on the Health and Safety Commission, alongside government agencies and employers. By older, more conservative, members ${ }^{70}$ this was seen as a notable achievement and, where matters of health and safety were concerned, they looked forward to a co-operative and constructive dialogue between the different social partners. Younger, more left-wing, activists, ${ }^{71}$ by contrast, were sceptical, favouring a much more radical and confrontational approach. The internal struggle for supremacy between these two elements tended to absorb the energy of unions, whose concerns were, in any case, primarily focused on issues of pay and conditions of employment. ${ }^{72}$ This situation continued throughout the 1970s until the "winter of discontent" brought the election of a Conservative government in 1979. This heralded a notable contraction of union influence and power and, as part of a general Conservative tendency towards deregulation of industry, a downgrading of health and safety issues on the wider political agenda. Prime Minister Margaret Thatcher's victorious confrontation with the National Union of Mineworkers during the winter of 1984-5 and a progressive decline in union membership, ${ }^{73}$ meant that British trade unions were increasingly preoccupied with their own survival during the 1980s. In this context their continuing neglect of health and safety matters is unsurprising. Moreover, in difficult times, they were unlikely to unite around a cause which apparently had no medical or scientific support.

Notwithstanding the general disarray of British trades unionism during the early 1980s, it is evident that the employment circumstances of the particular work group involved also contributed to the unions' apparent indifference to an occupational hazard. In Europe and elsewhere, the majority of workers diagnosed with organic solvent syndrome were painters. The prominence of this occupation in those workers affected appears to have arisen, in part, because they represented the largest identifiable section of the workforce who were exposed to solvents. Thus most of the numerous research projects which investigated the problem recruited painters as their study population. In addition, the participation of Danish painters in a vociferous campaign to highlight the problems of solvent exposure seems to have been instrumental in defining the disease as predominantly a disease of painters. Concerns about solvent exposure had been drawn into the labour struggles which took place in Denmark during the 1970 s. ${ }^{74}$ For this reason, engagement with the problem was more significant in Denmark than in other western European countries and the disease became more strongly identified with the particular Danish occupational group involved. In Denmark, painting was considered to be a highly skilled occupation involving a long apprenticeship, and painters were a powerful and well-organized section of the workforce. What had constituted a strength for the Danish painters, however, was unhelpful for their

Soc. Hist. Med., 2003, 16: 79-95; A J McIvor, A history of work in Britain, Basingstoke, Palgrave, 2001, pp. $111-47,200-40$.

${ }^{70}$ Notably Alfred Blyton and Vic Feather.

${ }^{71}$ Notably Sheila McKecknie and David Gee.
${ }^{72}$ Kenneth O Morgan, The people's peace: British history 1945-1990, Oxford University Press, 1990, pp. 397-433.

${ }^{73}$ Ibid., p. 450. Union membership fell from over 13 million in 1980 to under 10 million in 1983.

${ }^{74}$ Johansson and Partanen, op. cit., note 37 above, pp. $180-1$. 


\section{Anne Spurgeon}

British counterparts, who, by contrast, were regarded as unskilled and were poorly paid. Employment history has often underlined the importance of factors such as economic power, visibility and social status in facilitating access to better care and conditions at work. Organizational efficiency tends to promote circumstances where there are effective channels to communicate concerns and to demand both remedy and compensation. ${ }^{75}$ This was clearly not a situation in which British painters found themselves in the 1980s. Most were either self-employed small businessmen outside the remit of the HSE, or were unskilled labourers scattered in small groups around construction sites. The construction industry was well-known for its use of casual labour, lack of employment rights and its poor record on health and safety. ${ }^{76}$ Thus few of these workers were employed in large, well-organized industries with access to well-developed health and safety policies. Union membership, in so far as it existed at all, was likely to have been confined to unions covering construction workers in general, rather than painters in particular. Not unreasonably, such unions tended to prioritize safety rather than health. Set against the serious injuries and fatalities emanating from a continuing high rate of accidents in the construction industry, concerns about solvent exposure would have seemed trivial.

The invisibility of British painters can be contrasted with the much stronger voices of those industries which did have an interest in the problem of solvent exposure, not only because of the prospect of new regulations requiring greater protection for their workers, but also because of the possible effects on consumer demand for their products. Prominent among these companies were those involved directly or indirectly in the oil and chemical industries, which were strongly represented in the UK during the period. Like the HSE, such industries tended to adopt a watchful position during the 1980s, although they also carried out some defensive manoeuvres. In 1985, the European Chemical Industries' scientific advisory body, the European Council of Chemical Manufacturers Federation, met to consider what they were by now calling "Danish painter's syndrome". A statement subsequently issued to their members summarized their position on the matter, drawing attention to a number of concerns about the quality of the scientific evidence for the condition, concluding with the view that "there was no justification for reducing occupational exposure limits". ${ }^{77}$ In 1983 , the oil industry also decided to clarify its collective position on organic solvent syndrome, in this case by commissioning a comprehensive review of the literature on the subject. ${ }^{78}$ However, rather than reviewing the body of psychological data itself, which by this stage was substantial, ${ }^{79}$ the authors adopted an approach which sought to identify toxicological or medical data which might corroborate the claims of the psychologists. When such data failed to materialize, the case for organic

\footnotetext{
${ }^{75}$ This is well illustrated by the recognition of pneumoconiosis as a compensable disease in British miners in 1943. Similar recognition did not take place in the United States until 1969. In the early 1940s, British miners, unlike their American counterparts, were employed in a nationalized industry with a powerful union. Derickson, op. cit., note 47 above pp. 121-2, $151-61$.

${ }^{76}$ In 1984 there were 232.6 fatal or major injuries per 100,000 employees in the construction industry, compared with 87.4 per 100,000 employees in
}

manufacturing; Health and safety statistics, London, HMSO, 1985.

${ }^{77}$ Circular received by the Director of Medical Services, HSE, from the Health Protection Committee of CEFIC, 'Re: Danish painter's syndrome', 2 Dec, 1985.

${ }^{78}$ P Grasso, M Sharratt, D M Davies and D Irvine, 'Neurophysiological and psychological disorders and occupational exposure to organic solvents', Food Chem. Toxicol., 1984, 22 (10): 19-52.

${ }^{79}$ For a review of forty-five studies, see Spurgeon, op. cit., note 33 above. 


\section{Organic Solvent Syndrome in late-Twentieth-Century Britain}

solvent syndrome was deemed to be unproven. For several years, this influential review was quoted as defining the current UK position on the health effects of solvent exposure. Indirectly, it also underlined the UK position on neurobehavioural data, namely that such data lacked validity in their own right and could be considered only if backed up by "real" scientific evidence.

In the early 1980s the Policy Division of HSE seemed reasonably happy to endorse the position of the chemical industries on this subject and was disinclined to recommend any further regulatory action. However, following the 1985 international meetings, it also perceived the importance of keeping abreast of the emerging international position on organic solvents. To this end it arranged a series of three internal seminars to which a range of HSE's technical and medical specialists were invited. ${ }^{80}$ Essentially, these meetings were intended to provide an opportunity for ongoing debate on the subject. Misgivings about the Scandinavian data and the failure of the early British studies to support these had to be set against the increasing pressure to harmonize on matters of health and safety in the European Union. HSE's psychiatrist was dispatched to Denmark to gather information about the nature of the disease and how it was diagnosed, ${ }^{81}$ returning with the suggestion that culturally-based differences in disease nomenclature might account for some of the discrepancies between the British and mainland Europe position on this subject. In particular, attention focused on the use of the term "dementia" which, it was suggested, referred to one specific disease in the UK, but elsewhere in Europe encompassed a more general set of degenerative nervous system conditions. Other discussions revolved around possible differences in exposure conditions between the UK and elsewhere. It was suggested, for example, that traditional approaches to painting and decorating in the UK were less likely to result in prolonged high exposure to solvents. However, none of these explanations satisfactorily addressed the central question of whether the disease, regardless of its name or prevalence, actually existed.

By the late 1980s, the pressure to resolve this question was becoming difficult to resist. Since scepticism about the international data still prevailed amongst the regulatory authorities, a decision was taken to fund some further British-based research. The use of neurobehavioural techniques, although still viewed with suspicion, was reluctantly conceded, since it was important to produce data capable of comparison with other international evidence. The research contract was placed with the Institute of Occupational Health at the University of Birmingham and a large-scale study began in 1988. The results, published in 1992, showed that some very minor effects had occurred in workers who had been exposed to solvents for more than thirty years. ${ }^{82}$ However, it was noted that such effects were extremely small and might, in any case, be easily explained by the much higher exposures experienced by these workers in earlier years when working conditions were considerably worse. While it might, therefore, be wise to issue precautionary advice to employers, there was, it was concluded, no need for major regulatory action to reduce

\footnotetext{
${ }^{80}$ These were held at HSE headquarters in Nov. 1985, Nov. 1986 and April 1987. Personal communication from a member of the HSE's Advisory Committee on Toxic Substances.

${ }^{81}$ Ibid., April 1987. A consultant psychiatrist was appointed as Senior Employment Medical Advisor
}

for Mental Health in 1973; Employment Medical Advisory Service report, 1975-6, London, HMSO, 1978.

${ }^{82}$ Spurgeon, et al., op. cit., note 65 above. 


\section{Anne Spurgeon}

exposures. This approach chimed well with that already adopted by British legislators over previous years and appeared to vindicate the UK position. A second study, funded by ICI, was carried out in Birmingham the following year. ${ }^{83}$ This time the results were unambiguously negative. The acquisition of home-grown neurobehavioural data which supported the British position undoubtedly came as something of a relief to both policymakers and employers and at this point, the debate about organic solvent syndrome effectively closed in the UK. Either the disease did not exist at all or, if it did, it was unlikely to occur at levels of exposure common in British industry.

By the early 1990s official regulatory attitudes towards psychological testing had shown no noticeable change, although pressure from European partners created a certain amount of unease. Responding to this, in 1994, the HSE arranged an international meeting where government regulators and policymakers could discuss with psychological researchers from around the world how neurobehavioural data might be used to set occupational exposure standards. ${ }^{84}$ During two days of debate, the incompatibility between neurobehavioural data and the British regulatory approach was repeatedly underlined. The conclusions noted, for example, that "the workshop has emphasised the need for researchers to tailor neurobehavioural studies, both in design ... and reporting, to the requirements of regulatory toxicology", 85 and that HSE was "looking at parallels that can be drawn between neurobehavioural and physiological test models" ${ }^{86}$ Meanwhile scientific papers and government reports throughout the period were peppered with comments which reveal an enduring attitude of scepticism towards psychological methods. When, for example, a neurobehavioural study was published in the Lancet in $1995,{ }^{87}$ which investigated the neurotoxicity of organophosphate pesticides, the then Minister of Agriculture, Angela Browning, expressed the view that the results could not be acted upon since we needed "proper scientific research into the subject and we did not yet have this" ${ }^{88}$ Neurobehavioural testing was apparently regarded with suspicion by scientists, doctors and legislators alike and it is clear that the use of psychological methods had no strong advocate among any of these groups. Meanwhile, elsewhere in the world, this form of assessment had, by the 1980s, become an indispensable tool in the investigation of the early health effects of exposure to occupational and environmental neurotoxicants.

The considerable influence of neurobehavioural toxicology and the new role of psychologists in occupational and environmental research, in both Europe and the United States, has perhaps been underestimated in some historical analyses of this period. ${ }^{89}$ For many of the new concerns about low-level chemical exposure the results of

\footnotetext{
${ }^{83}$ A Spurgeon, D C Glass, I A Calvert, M Cunningham-Hill, et al., 'Investigation of dose-related neurobehavioural effects in paintmakers exposed to low levels of solvents', Occup. Environ. Med., 1994, 51: 626-30.

${ }^{84} \mathrm{R}$ Stephens and P Barker, 'The role of human neurobehavioural tests in regulatory activity on chemicals', Occup. Environ. Med., 1998, 55: 210-14.

${ }^{85}$ Ibid., p. 213.

${ }^{86}$ Ibid., pp. 213-14.

${ }^{87}$ R Stephens, A Spurgeon, J Beach, I A Calvert, et al., 'Neuropsychological effects of long-term
}

exposure to organophosphates in sheep dip', Lancet, 1995, 345: 1135-38.

${ }^{88}$ Angela Browning was interviewed on Channel 4 News in Feb. 1995 about the problem of OP poisoning among sheep farmers.

${ }^{89}$ For example, two recent histories of lead poisoning mention psychological tests only briefly in the context of childhood poisoning and IQ tests. Markowitz and Rosner, op. cit., note 23 above, pp. 122-3, 135-6; Warren, op. cit., note 47 above, p. 148. However, early concerns about low level lead exposure were based almost exclusively on 


\section{Organic Solvent Syndrome in late-Twentieth-Century Britain}

neurobehavioural tests represented the only evidence of health effects. ${ }^{90}$ Thus, in many cases, acceptance of this type of data was a prerequisite for the acknowledgement of the effects themselves. In Scandinavian countries this acceptance was almost total, within both the scientific and medical communities, and government regulatory bodies. ${ }^{91}$ In the United States, despite some on-going controversy in the scientific literature, ${ }^{92}$ there was broad acceptance at government level. ${ }^{93}$ In Britain, however, there were serious doubts in all quarters. It seemed that, for neurobehavioural methods to succeed, they needed a champion in the form of a promotional professional group. Since the methods were psychological in origin, the obvious candidate for this role was the profession of psychology. Experience elsewhere suggested that neurobehavioural toxicology offered the prospect of a new and interesting field of endeavour for psychologists, with all its attendant opportunities for career development and even financial gain. ${ }^{94}$ Strangely, however, the subject was largely ignored by the British psychology profession and, as a result, no challenge to the deep scepticism of the medical and scientific community emerged.

Part of the reason for this was undoubtedly the dearth of psychologists employed in occupational health in the UK. British psychologists have never played a prominent role in matters of workplace health and safety, and, where they have featured, this has been largely in relation to matters of fatigue and occupational stress. ${ }^{95}$ The adverse effects of chemicals have tended to be the preserve of toxicologists, epidemiologists and physicians, with heavy emphasis on population studies and animal experimentation. During the early 1980s, few psychologists in the UK had any direct involvement with the subject of organic solvent syndrome. The psychologist who had supervised the research at the LSHTM subsequently left for Canada to pursue a new career in medicine. Other academic departments of occupational health, which were in any case rather few in number, did not have any psychologists on their staff until 1985, and numbers remained in single figures after that date. ${ }^{96}$

At the HSE, a psychologist, alongside a psychiatrist and a psychiatric social worker, had, by the early 1980s, been appointed to EMAS. ${ }^{97}$ The acquisition of this particular mix of skills, however, strongly reflected the traditional model of community-based social care,

neurobehavioural data. See, for example, R G Feldman, N L Ricks, E L Baker, 'Neuropsychological effects of industrial toxins: a review', Am. J. Ind. Med., 1980, 1: 211-27; also, B Weiss, 'Behavioral toxicology and environmental health science', Am. Psychol., 1983, 38: 1174-87.

${ }^{90}$ For example, for the effects of low-level methylmercury exposure, see Crump, et al., op. cit., note 29 above. For a discussion of other syndromes, see D E Hartman, 'Neuropsychological toxicology: identification and assessment of neurotoxic syndromes', Arch. Clin. Neuropsychol., 1987, 2 (1): $45-65$.

${ }^{91}$ Two rare examples of published disagreement with the official Danish position can be found in E O Errebro-Knudsen and F Olsen, 'Organic solvents and presenile dementia (the painters' syndrome). A critical review of the Danish literature', Sci. Total Environ., 1986, 48 (1-2): 45-67; A Gade,
E L Mortensen, P Bruhn, “ "Chronic painter's syndrome": a reanalysis of psychological test data in a group of diagnosed cases, based on comparisons with matched controls', Acta Neurol. Scand., 1988, 77 (4): 293-306.

${ }^{92}$ P R Lees-Haley and C W Williams,

'Neurotoxicity of chronic low-dose exposure to organic solvents: a skeptical review', J. Clin. Psychol., 1997, 53 (7): 699-712.

${ }_{93}$ This was enshrined in the Occupational Safety and Health Act of 1970 .

${ }^{94}$ Weiss, op. cit., note 89 above, p. 1180.

${ }^{95}$ Shimmin and Wallis, op. cit., note 25 above, pp. 3-6, 98-101.

${ }^{96}$ There were three university departments in England and two in Scotland.

${ }_{97}$ A psychologist and a social worker with training as a psychiatric nurse were appointed to EMAS in 1976. EMAS, op. cit., note 81 above. 


\section{Anne Spurgeon}

thus underlining the assumption that the role of this section of the organization was to address mental health issues in the workplace, rather than problems resulting from chemical damage to the nervous system. The appointment was primarily a response to growing concerns about occupational stress. In fact, the particular psychologist appointed to HSE also had skills in the related field of ergonomics. This was an important factor since certain employment trends at the time dictated that his work was focused primarily on ergonomic issues. During the early 1980s, computers or "visual display units" (VDUs) were rapidly replacing electric typewriters in workplaces around the country. As a consequence thousands of office staff were experiencing radical changes in the way they worked, precipitating an epidemic of physical and psychosocial occupational health problems. There were, for example, reports of excessive fatigue, complaints about eye-strain and about repetitive strain injury and, most worrying of all, a suspicion that radiation emanating from computers was damaging the unborn children of pregnant workers. ${ }^{98}$ Unsurprisingly these problems were accompanied by a large amount of psychological distress. For the HSE this was a matter of major importance and one with which the newly appointed psychologist/ ergonomist was centrally involved. In a department that contained only a solitary psychologist, this was a heavy workload. The rather more limited time spent on assessing the merits or otherwise of organic solvent syndrome should therefore be viewed against this background. In the UK, no one was complaining about solvents, but plenty of people were worried about VDUs.

It is clear that psychologists concerned with occupational health issues in general and with neurotoxicological issues in particular were in short supply in the UK. Although this was due in part to the scientific traditions of the health and safety profession, this cannot be considered a complete explanation. In some other countries in western Europe, psychologists had gradually developed a strong presence in this field, in parallel with the development of their profession as a whole. Moreover, in the UK, psychologists had acquired a central position in certain other fields of healthcare where they had originally enjoyed only a subsidiary role. ${ }^{99}$ To understand the failure of British psychologists to become major players in the field of occupational health and, as a consequence, their failure to become major advocates for neurobehavioural toxicology, it is necessary to examine the development and organization of psychological practice in the UK and its advance towards professionalization over the preceding fifty years.

During the second half of the twentieth century, psychology as a discipline showed unprecedented growth. Membership of the professional body, the British Psychological Society (BPS) increased from just over 800 when records began in 1941 to 2655 in 1960. By the end of the twentieth century, however, this figure was approaching 27,000, despite the introduction of more stringent membership criteria. ${ }^{100}$ The 1960 s expansion in higher education witnessed, in particular, a growth in the popularity of the social sciences and

\footnotetext{
${ }^{98}$ For a summary of their concerns, see Visual display terminals and workers' health, WHO Offset Publication No. 99, Geneva, WHO, 1987.

${ }^{99}$ By 1980 psychologists had established grades linked to national salary structures in the NHS, the Education Department (School
}

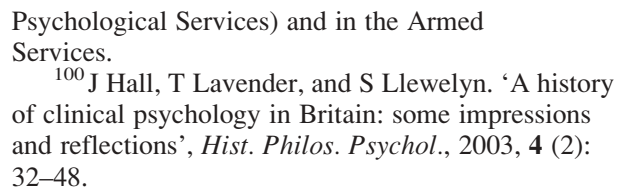




\section{Organic Solvent Syndrome in late-Twentieth-Century Britain}

allied subjects. As a result, large numbers of psychology graduates began to emerge from British universities and to practise as psychologists on the strength of their first degrees. The BPS had long been exercised about the competence of those calling themselves psychologists and this expansion brought such concerns into sharp focus. In 1958, the BPS closed its membership to those lacking an approved first degree in psychology and the following decade saw a rapid movement towards specialist training courses which delineated further those with more advanced knowledge or competence. Specialist "Divisions" were created which admitted only those with approved postgraduate qualifications, Practising Certificates were issued and, in 1988, with the granting of a Royal Charter, a Register of Chartered Psychologists was opened. ${ }^{101}$ Thus growth was accompanied by the development of structures and systems modelled closely on those of the medical profession. ${ }^{102}$ By the 1980 s psychology abounded with regulations and examinations, approved courses and competencies and all the diverse accoutrements of a fully-fledged profession.

There were at least two important effects of these developments. First, the content of the various specialist fields in psychology became more rigidly defined, essentially by the content of the approved training courses. Second, the particular people who could practise in these fields were strictly limited to those who had completed the said courses. Two such specialities, those of clinical psychology and occupational psychology, contained elements that were potentially relevant to the field of occupational health in general and the identification of organic solvent syndrome in particular. However, by the early 1980s, the organization of the profession was such that neither was likely to view these issues as falling within their remit.

Clinical psychologists who, by the mid-1990s, were the product of three years professional postgraduate training, accompanied by an optional specialist accreditation in neuropsychology, were those most likely to administer psychological tests in the context of the assessment of brain damage. However, these psychologists worked almost exclusively in the NHS, drawing their clients from referrals within this structure. Their neuropsychological skills were usually applied to patients suffering from degenerative nervous system disease, head injury or stroke. They would have had little or no involvement with clients drawn from an occupational setting, except perhaps in cases of accidental trauma or the occasional follow-up of patients hospitalized following a serious poisoning incident.

Occupational psychologists, with their focus on the workplace, were better placed than their clinical counterparts to be aware of occupational disease. However, for somewhat different reasons, they would also have been uninterested in organic solvent syndrome. During the years since the formation of the Division of Occupational Psychology in 1975, occupational psychologists had progressively delineated their sphere of activity to encompass management and organizational issues, personnel selection and training as well as aspects of occupational stress. ${ }^{103}$ Working largely in private practice, members of this

\footnotetext{
${ }^{101}$ The Register of chartered psychologists and the accompanying Directory of chartered psychologists (those with practising certificates) are published annually, Leicester, BPS.

${ }^{102}$ The processes of professionalization in psychology have been less discussed by historians than have aspects of professonalization in medicine. However, see S Lovie, 'Three steps to
}

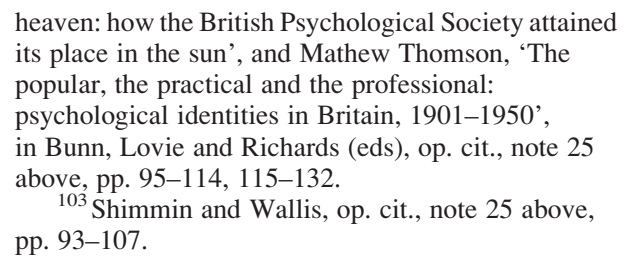

heaven: how the British Psychological Society attained its place in the sun', and Mathew Thomson, 'The popular, the practical and the professional: psychological identities in Britain, 1901-1950', in Bunn, Lovie and Richards (eds), op. cit., note 25 above, pp. 95-114, 115-132.

${ }^{103}$ Shimmin and Wallis, op. cit., note 25 above, pp. 93-107. 


\section{Anne Spurgeon}

group were usually hired by organizations in response to problems identified by employers. Inevitably, such problems tended to emerge within a perspective of concern about performance rather than health. To an employer, the effects of chemical exposure were matters for the occupational hygienists or the occupational physician or nurse. Occupational psychologists would similarly have considered themselves unsuited by background and training to address such issues, an attitude further reinforced by BPS rules pertaining to the use of psychological tests.

The years following the institution of the Division of Clinical Psychology were marked by progressive restrictions on the use of such tests and the introduction of specialist licensing. ${ }^{104}$ This culminated in the establishment of an intricate system of test categorization and grading designed to prevent use by "non-approved" (i.e. non-specialist trained) individuals. The administration of certain neuropsychological tests would therefore have been considered by most occupational psychologists to be professionally inappropriate and, worse, likely to result in disciplinary action by the BPS. Many of the tests subject to restrictions in the UK are, in fact, used freely by psychologists and non-psychologists alike around the world. However, the frequent use of such tests by medical doctors and others in the course of neurobehavioural investigations would have evoked special disapproval amongst British psychologists who had been engaged in a long struggle to transform their work from that of a psychometric technician to skilled diagnostician and therapist. The recommendations of the Trethowan Committee in 1977, that clinical psychology within the NHS should be viewed as an independent profession with specialist skills (including proficiency in testing), was a hard won and jealously guarded achievement. ${ }^{105}$

Against this background, it is not difficult to understand why organic solvent syndrome and neurobehavioural toxicology effectively fell down the cracks between the different psychological specialties with their powerful professional agendas. Moreover, any stimulus from academic psychology, which might have provided the impetus for BPS involvement was not forthcoming. Academic psychologists, occupied primarily with teaching and research, and thus less concerned with the strictures of professional practice, might have been expected to develop a level of interest which was at least comparable to that of their colleagues abroad. However, British academic involvement with the subject was relatively short-lived. This owed much to the dearth of psychologists in academic departments of occupational health, already alluded to, since academics from mainstream university psychology departments would have had little exposure to the occupational health literature. By the late 1980s, there were five academic departments of occupational health in the UK, but only two of these had a psychologist on their staff. Both were briefly engaged with neurobehavioural work in the early 1990s, but the subject failed to develop into a significant field of academic research. The Department of Occupational Medicine in Manchester published a small neurobehavioural study in 1988

\footnotetext{
${ }^{104}$ Beginning in 1987, standards and competence requirements, with approved training courses, for the use of psychological tests became formalized in: Psychological testing: a test user's guide, Leicester, Psychological Testing Centre of the BPS, 1999, see also http://www.psychtesting.org.uk. Alongside this, NFER-Nelson, one of the main test publishers in the
}

UK, requires purchaser registration and, based on qualifications, issues Test User Codes which determine the level of test which can be purchased by each user.

${ }^{105}$ The role of psychologists in the health services: report of the Sub-Committee on the Role of Psychologists in the Health Services (Trethowan Report), London, HMSO, 1977. 


\section{Organic Solvent Syndrome in late-Twentieth-Century Britain}

which investigated the longer term effects of a solvent poisoning incident in a group of workers. ${ }^{106}$ As such, this was not strictly relevant to the question of organic solvent syndrome which was supposed to result from long-term, low-level exposure. The Institute of Occupational Health in Birmingham carried out the neurobehavioural study funded by HSE in $1988,{ }^{107}$ and the subsequent study for ICI was completed in the early 1990s. ${ }^{108}$ Essentially, these investigations, with their largely negative outcomes, marked the end of the UK's active engagement with the subject of organic solvent syndrome for several years.

Apart from a brief application to the problem of pesticide exposure in farmers during the mid-1990s, ${ }^{109}$ neurobehavioural toxicology also largely disappeared from view in the UK at this point. It had only come to any kind of prominence because of the question of organic solvent syndrome. While researchers in other parts of Europe and the United States actively pursued the investigation of other putative neurotoxicants using neurobehavioural techniques, those in the UK had little opportunity to follow a similar path. The few psychologists who had gained experience with neurobehavioural methods were employed outside mainstream psychology in multidisciplinary academic occupational health departments. They were unsupported by their own discipline which, far from being interested in the field, was likely to disapprove actively of the use of psychological tests for such purposes and under such conditions. Within occupational health itself, the expectation remained that psychologists should be largely concerned with psychosocial problems associated with occupational stress. ${ }^{110}$ Moreover, the lack of academic motivation to pursue and develop neurobehavioural work should also be seen in the wider context of the limited financial resources available for occupational health research in the UK. When, in the late 1990s, another group of British scientists revisited the problem of organic solvent syndrome, it is interesting to note that they rejected neurobehavioural toxicology in favour of a classically epidemiological approach, something which was well understood and accepted within the traditions of occupational medicine. ${ }^{111}$

\section{Conclusion}

The failure of organic solvent syndrome to gain acceptance in the UK has been traced, in part, to the inaction of a number of interested parties, notably government regulators, workers and employers, who, for different reasons, were reluctant or unable to recognize the condition. In the case of workers and employers, much of the failure of the disease to gain recognition can be attributed to the way the relevant work groups were organized and to the distribution of power and influence amongst interested parties in the political climate and employment circumstances of the time. Importantly, however, those who wished to discredit the disease were able to point to the dubious nature of the non-medical techniques employed to diagnose it, something which found ready support within the relevant regulatory authorities. Mistrust of psychologically-based diagnostic methods amongst

\footnotetext{
${ }^{106}$ B Stollery and M L H Flindt, 'Memory sequelae of solvent intoxication', Scand. J. Work Environ. Health, 1988, 14: 45-8.

${ }^{107}$ Spurgeon, et al., op. cit., note 65 above.

${ }^{108}$ Spurgeon, et al., op. cit., note 83 above.

${ }^{109}$ Stephens, et al., op. cit., note 87 above.
} 


\section{Anne Spurgeon}

medical and scientific personnel within these departments can be traced to historical approaches to the selection and use of scientific information in the regulatory processes in the UK, and to the disciplinary backgrounds of those traditionally involved in this process. Further, this prevailing scepticism remained largely unchallenged since no strong advocate for the techniques concerned emerged from the psychology profession during the period. The increasing professionalization of psychology which took place during the second half of the twentieth century effectively created a system of specialties with tightly drawn boundaries of membership based on precisely defined areas of competence. This left an innovative application like neurobehavioural toxicology outside the remit of any existing field of psychology and thus lacking a champion for its cause. While the techniques became well-established elsewhere in Europe, therefore, they remained on the fringes of scientific respectability in the UK.

Interestingly, the international debate on organic solvent syndrome seemed set to reopen during the closing years of the twentieth century. A number of papers began to appear in the scientific literature, which, if not directly challenging the reality of the disease, at least drew attention to the wide variation in numbers of cases in different countries. ${ }^{112}$ Between 1980 and 1998, for example, Denmark, the most enthusiastic proponent of the disease, recorded over 5500 cases, while Switzerland identified only six. It was further noted that different clinics used widely different diagnostic criteria and different tests in the course of assessment. ${ }^{113}$ Meanwhile the new enthusiasm for evidence-based medicine spawned a number of systematic reviews on the subject which questioned both the strength and the consistency of the evidence for organic solvent syndrome and the biological plausibility of the condition. Solvents, it was noted, were a very diverse group of compounds and it was therefore unrealistic to expect that they would all have the same effects. ${ }^{114}$

In Britain, there continued to be no formal recognition of organic solvent syndrome and thus no statutory compensation for the disease. Notwithstanding their official position on the subject, however, the UK regulatory authorities progressively reduced the occupational exposure limits for various solvents during the 1990s, so that British workers enjoyed the same level of protection as their counterparts in the rest of the European Union. The HSE issued posters and leaflets designed to raise awareness of the possible dangers of solvents and, although these contained no explicit reference to organic solvent syndrome, the adoption of water-based substitutes for solvent-based paints was recommended and became widespread. In many ways, therefore, the UK began to operate as though it recognized the risk of a disease whose existence it had never formally acknowledged. With its peculiar mix of social, regulatory and professional relationships, therefore, Britain appeared somehow to have weathered a European storm with the minimum of local disruption.

and neuropsychological symptoms', Occup. Environ. Med., 1999, 56: 383-7.

${ }^{112}$ Triebig and Hallermann, op. cit., note 8 above.

${ }^{113}$ The differences in criteria were highlighted by J A van der Hoek, M M Verberk, G van der Laan, and G Hageman, 'Routine diagnostic procedures for chronic encephalopathy induced by solvents: survey of experts', Occup. Environ. Med., 2001, 58: 382-5.

${ }^{114}$ See, for example, J F Gamble, 'Low-level hydrocarbon solvent exposure and neurobehavioural effects', Occup. Med. (London), 2000, 50 (2): 81-102; Lees-Haley and Williams, op. cit., note 92 above. 